\title{
Late Holocene summer temperatures in the central Andes reconstructed from the sediments of high-elevation Laguna Chepical, Chile $\left(32^{\circ} \mathrm{S}\right)$
}

\author{
R. de Jong ${ }^{1}$, L. von Gunten ${ }^{2}$, A. Maldonado ${ }^{3}$, and M. Grosjean ${ }^{1}$ \\ ${ }^{1}$ Oeschger Centre for Climate Change Research \& Institute of Geography, University of Bern, Bern, Switzerland \\ ${ }^{2}$ PAGES International Project Office, Bern, Switzerland \\ ${ }^{3}$ Centro de Estudios Avanzados en Zonas Aridas CEAZA, Universidad de La Serena, La Serena, Chile \\ Correspondence to: R. de Jong (dejong@ giub.unibe.ch)
}

Received: 15 April 2013 - Published in Clim. Past Discuss.: 6 May 2013

Revised: 4 July 2013 - Accepted: 5 July 2013 - Published: 15 August 2013

\begin{abstract}
High-resolution reconstructions of climate variability that cover the past millennia are necessary to improve the understanding of natural and anthropogenic climate change across the globe. Although numerous records are available for the mid- and high-latitudes of the Northern Hemisphere, global assessments are still compromised by the scarcity of data from the Southern Hemisphere. This is particularly the case for the tropical and subtropical areas. In addition, high elevation sites in the South American Andes may provide insight into the vertical structure of climate change in the mid-troposphere. This study presents a $3000 \mathrm{yr}$-long austral summer (November to February) temperature reconstruction derived from the ${ }^{210} \mathrm{~Pb}$ - and ${ }^{14} \mathrm{C}$-dated organic sediments of Laguna Chepical $\left(32^{\circ} 16^{\prime} \mathrm{S}, 70^{\circ} 30^{\prime} \mathrm{W}\right.$, $3050 \mathrm{~m}$ a.s.l.), a high-elevation glacial lake in the subtropical Andes of central Chile. Scanning reflectance spectroscopy in the visible light range provided the spectral index $R_{570} / R_{630}$, which reflects the clay mineral content in lake sediments. For the calibration period (AD 1901-2006), the $R_{570} / R_{630}$ data were regressed against monthly meteorological reanalysis data, showing that this proxy was strongly and significantly correlated with mean summer (NDJF) temperatures $\left(R_{3 \mathrm{yr}}=-0.63, p_{\text {adj }}=0.01\right)$. This calibration model was used to make a quantitative temperature reconstruction back to $1000 \mathrm{BC}$.

The reconstruction (with a model error $\mathrm{RMSEP}_{\text {boot }}$ of $0.33^{\circ} \mathrm{C}$ ) shows that the warmest decades of the past $3000 \mathrm{yr}$ occurred during the calibration period. The 19th century (end of the Little Ice Age (LIA)) was cool. The prominent warmth
\end{abstract}

reconstructed for the 18th century, which was also observed in other records from this area, seems systematic for subtropical and southern South America but remains difficult to explain. Except for this warm period, the LIA was generally characterized by cool summers. Back to AD 1400, the results from this study compare remarkably well to low altitude records from the Chilean Central Valley and southern South America. However, the reconstruction from Laguna Chepical does not show a warm Medieval Climate Anomaly during the 12-13th century, which is consistent with records from tropical South America. The Chepical record also indicates substantial cooling prior to $800 \mathrm{BC}$. This coincides with well-known regional as well as global glacier advances which have been attributed to a grand solar minimum. This study thus provides insight into the climatic drivers and temperature patterns in a region for which currently very few data are available. It also shows that since ca. AD 1400, longterm temperature patterns were generally similar at low and high altitudes in central Chile.

\section{Introduction}

High-resolution (annual-subdecadal), well-calibrated reconstructions of climate variables for the past $2000 \mathrm{yr}$ are needed for the detection of climate variability and the attribution of changes to forcing factors (PAGES 2k Consortium, 2013). Considerable efforts were made to synthesize heterogeneous climatic information (diverse proxies, different 
spatial and temporal scales of reconstructions) and to provide comprehensive large-scale temperature reconstructions (e.g. Luterbacher et al., 2004; Mann et al., 2009; PAGES 2k Consortium, 2013; Trachsel et al., 2012). However, global reconstructions are still compromised by a lack of data from the tropics and the Southern Hemisphere. For South America, recent research efforts aimed at compiling existing highresolution proxy data and to stimulate new research in this region (Villalba et al., 2009 and references therein). Despite these efforts, for the first spatially explicit temperature reconstruction for the Southern Hemisphere (representing southern South America: Neukom et al., 2011), only five highly resolved proxy-based temperature records were available for the entire continent going further back than AD 1500. A regional-scale temperature reconstruction for tropical South America was therefore not possible, whereas the regional scale temperature reconstruction for the subtropics in South America was hampered by the complete absence of temperature reconstructions between $14-34^{\circ} \mathrm{S}$. However, the importance of homogenous spatial representation of proxy data across the continents and hemispheres has recently been demonstrated in the context of the global assessment of climate sensitivity to past greenhouse gas perturbations (Schmittner et al., 2011).

A second largely unresolved problem in palaeoclimatology is the question of how climate change may have varied along the vertical structure of the troposphere and between high and low elevation sites (Diaz et al., 2003). As shown by e.g. Bradley et al. (2006) for the tropical Andes and by Falvey and Garreaud (2009) for the sub-tropical Chilean Andes $\left(17-30^{\circ} \mathrm{S}\right)$, recent multi-decadal temperature trends between high and low elevation sites differed strongly; sites at the Pacific coast experienced strong cooling trends (1979$2006,-0.2^{\circ} \mathrm{C}$ per decade) while higher elevation sites in the Andes were warming at the same time $\left(+0.25^{\circ} \mathrm{C}\right.$ per decade). It has long been known that several major climatic processes and modes dominating at hemispheric and interhemispheric scales are also operating in South America (e.g. El Niño Southern Oscillation ENSO, Southern Annular Mode SAM, Pacific Decadal Oscillation PDO, Garreaud et al., 2009). However, the influence of these climatic modes on high altitude areas, in particular in the subtropical and tropical regions of South America, is largely unknown.

In this study, we present a 3000 yr-long austral summer temperature reconstruction at sub- to multi decadal resolution from high altitude Laguna Chepical $\left(32^{\circ} 16^{\prime} \mathrm{S}, 70^{\circ} 30^{\prime} \mathrm{W}\right.$, 3050 m a.s.l.) in the subtropical Andes of Central Chile. So far, past temperature variability in this high altitude region has been inferred from large-scale teleconnections with remote sites from the tropical Pacific or glaciers from Peru (e.g. Neukom et al., 2011), since local long tree ring records in this area reflect precipitation (Boninsegna et al., 2009 and references therein) and other records are not available. The nearest study providing a summer temperature reconstruction is Laguna Aculeo in the Chilean Central Valley $\left(34^{\circ} \mathrm{S}\right.$,
$355 \mathrm{~m}$ a.s.l.; von Gunten et al., 2009b), an area that shows a markedly different structure of summer temperature compared to subtropical South America (Neukom et al., 2011).

The sediments of Laguna Chepical were analyzed using hyperspectral imaging techniques. The sediment proxies were regressed against meteorological data ("calibration in time" with temperature and precipitation data), which showed that the spectral index Reflectance $570 \mathrm{~nm} /$ Reflectance $_{630 \mathrm{~nm}}\left(R_{570} / R_{630}\right)$ was strongly and significantly negatively correlated with summer temperatures. This spectral index is known to be indicative of the clay mineral content in lake sediments. We reason that cool summers, associated with late lake ice break-up and hence relatively long periods of ice cover, favor the settling of very fine particles in the lake, which leads to increased clay contents in the sediments. The calibration model was applied to the spectral index $\left(R_{570} / R_{630}\right)$ measured on the lake sediments representing the past $3000 \mathrm{yr}$, providing a reconstruction of summer temperature anomalies and associated reconstruction errors. We then compared this temperature reconstruction to the very few available regional temperature reconstructions and place it in the context of Late Holocene temperature variability in South America.

\section{Site description}

Central Chile lies in the transition zone between the Southern Hemisphere mid-latitude westerlies and the South Pacific Anticyclone SPAC (Garreaud et al., 2009). In summer, a strong SPAC blocks the northward migration of westerlies, causing relatively dry, warm conditions. In austral winter, the westerly wind belt and associated cyclones shift northward, resulting in higher precipitation in central Chile (Fig. 1b). The El Niño Southern Oscillation (ENSO) drives interannual variability in winter precipitation, with warm ENSO phases leading to enhanced precipitation (Aceituno, 1988).

Figure $1 \mathrm{~b}$ shows the climatic characteristics of the study area, with the semiarid dry summer and cold winter climate (BSk Köppen classification). Temperature data in this figure were derived from the nearest high-altitude meteorological station Christo Redentor (Fig. 1a: $32.50^{\circ} \mathrm{S}, 70.05^{\circ} \mathrm{W}$, $3109 \mathrm{~m}$ ), whereas precipitation data were available from reanalysis data (Mitchell and Jones, 2005). Mean annual temperature measured at the station is $-1.6^{\circ} \mathrm{C}$ (www.mineria. gov.ar), whereas the average annual number of freezing days was 308 days. Total annual precipitation is $360 \mathrm{~mm}$, which primarily falls during the winter months (Fig. 1b).

Laguna Chepical is a $12.9 \mathrm{~m}$ deep, small $\left(0.57 \mathrm{~km}^{2}\right)$ highelevation glacial lake on the western flank of the Andean Cordillera in Central Chile $\left(32^{\circ} 16^{\prime} \mathrm{S} / 70^{\circ} 30^{\prime} \mathrm{W}, 3050 \mathrm{~m}\right)$. It is located ca. $130 \mathrm{~km}$ north of Santiago de Chile (Fig. 1). The catchment is $14.5 \mathrm{~km}^{2}$ and ranges up to $3600 \mathrm{~m}$. The bedrock is composed of Lower Miocene basaltic, andesitic and dacitic lavas, breccias and pyroclastic rocks (SERNAGEOMIN, 

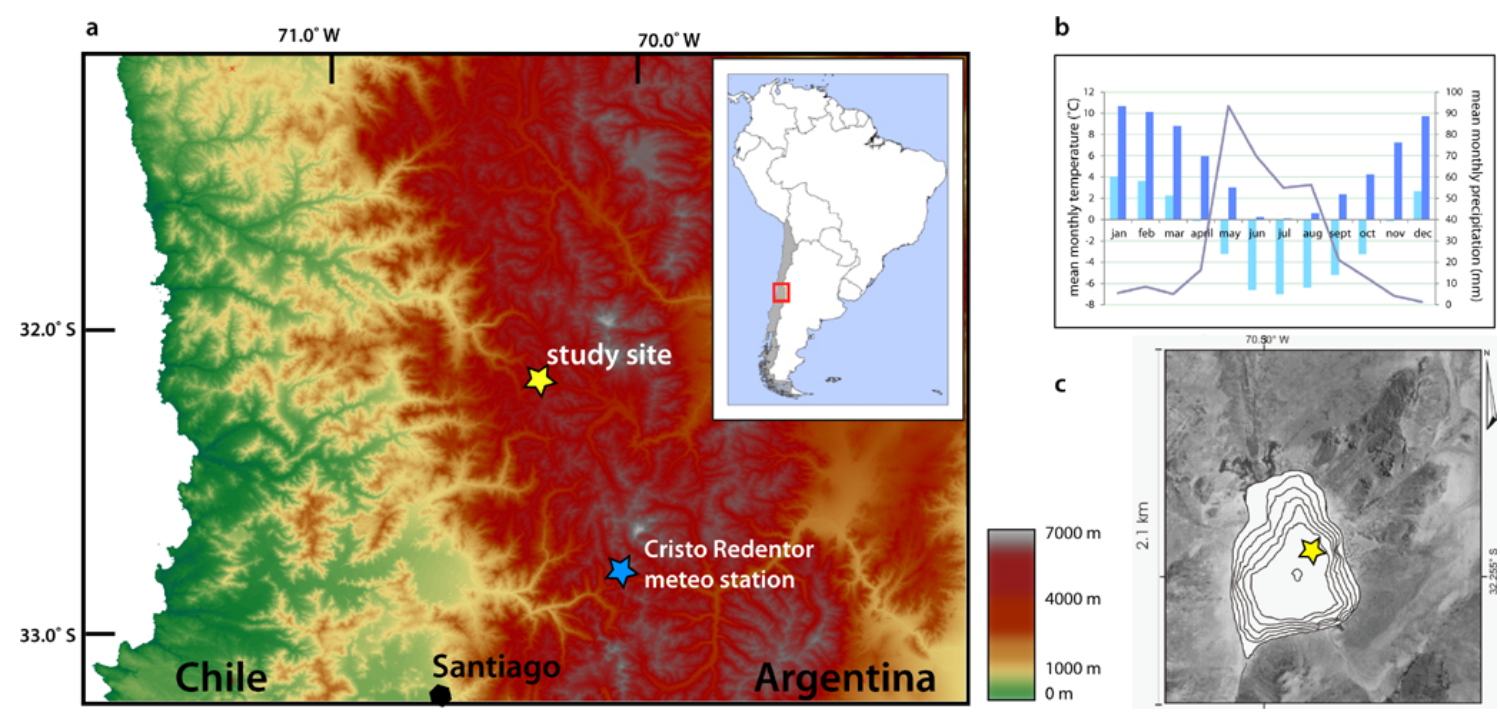

Fig. 1. (a) Overview map of the study area, showing the location of the study area in the high central Andes of Chile and the location of the nearest high-altitude meteorological station Cristo Redentor. (b) Annual distribution of monthly mean precipitation and temperatures. The dark blue bars represent mean monthly values from the reanalysis data (Mitchell and Jones, 2005; AD 1901-2006) for the $0.5 \times 0.5^{\circ} \mathrm{C}$ gridcell representing Laguna Chepical, whereas light blue bars show monthly means between AD 1940-1982 from the Cristo Redentor meteorological station (3109 m a.s.1.). The offset is likely due to the on average lower altitudes of the reanalysis grid cell. Precipitation falls almost exclusively during the winter months, at high altitudes in the form of snow. (c) Lake bathymetry and coring location of the cores CHEP 06/03 and 06/04.

2003). The area was ice-covered during the last Glacial Maximum. Vegetation around the lake belongs to the Upper Andean vegetation belt with cushion plants and shrubs with 20 $30 \%$ surface cover.

Laguna Chepical is oligotrophic $\left(0.1-0.15 \mathrm{mg} \mathrm{L}^{-1} \mathrm{PO}_{4}\right.$, $1-2 \mathrm{mg} \mathrm{L}^{-1} \mathrm{NO}_{3}$ ), cold monomict (stratified in winter under ice cover, not stratified in late summer when measured in 2006). When measured (on 9 March 2006), water temperatures (around $\left.12.5^{\circ} \mathrm{C}\right), \mathrm{pH}(7.5)$ and conductivity $\left(105 \mu \mathrm{S} \mathrm{cm}^{-1}\right)$ were nearly homogenous over the entire water column. During a reconnaissance visit on 31 October 2005, the lake was frozen solid. To infer the approximate duration of ice cover on this lake, we re-calculated water surface temperatures measured in Laguna Encañado ( $33^{\circ} 40^{\prime} \mathrm{S}, 70^{\circ} 08^{\prime} \mathrm{W}, 2490 \mathrm{~m}$; von Gunten, 2009) by applying the adiabatic temperature lapse rate. This approximation indicates that Laguna Chepical is likely ice-covered from midApril/May until mid-November/December, thus 7-9 months.

A small creek with episodic flow enters the lake in the northwestern side and has formed a small, shallow delta. Additional sediment inflow likely occurs during snow melting from the surrounding slopes to the N, E and W. The lake bathymetric map (Fig. 1c) reflects the position of the inflow as well as the flat bottom topography in the central deepest part of the lake. An outflow is located in the SW. Since ca. AD 1885, this outflow was dammed and regulated (A. Espinoza, personal communication, 2006). Due to very low precipitation rates in this region, inflow into the lake is limited and transport of clastic sediments is minimal. Wind and turbulent mixing of the lake in summer is very strong. Hence most of the very fine clastic fraction (very fine silt or clay) remains in suspension and only settles under calm conditions in winter when the lake is frozen.

\section{Materials and methods}

\subsection{Field and laboratory methods, chronology}

During the fieldwork in March 2006, a bathymetric map was made with a Garmin GPSMAP 178 Echosounder and four sediment cores were collected from the central part of Laguna Chepical using a UWITEC gravity corer. The core CHEP 06/03 (82 cm long from $12.9 \mathrm{~m}$ water depth) was selected for the analysis and split in two halves (A and B). Both half-cores were scanned using non-destructive techniques (see below). Subsequently, half A was sub-sampled at $2 \mathrm{~mm}$ resolution and used for the analysis of total biogenic silica (bSi), total carbon (TC), total nitrogen (TN), C:N, water content and spheroidal carbonaceous particles (SCPs). Core half $\mathrm{B}$ was subsampled in $5 \mathrm{~mm}$ slices and used for ${ }^{210} \mathrm{~Pb},{ }^{137} \mathrm{Cs}$ and ${ }^{14} \mathrm{C}$ dating. For replication, parallel core CHEP 06/04 was also scanned and subsampled at $5 \mathrm{~mm}$ resolution for the measurement of loss of ignition (LOI). All samples were weighed and freeze-dried prior to further analysis, and water content was determined.

Scanning in situ reflectance spectroscopy in the visible range $380-730 \mathrm{~nm}$ (VIS-RS) was performed with 
a GretagMcBeth Spectrolino spectrophotometer $(10 \mathrm{~nm}$ spectral resolution, $2 \mathrm{~mm}$ sampling resolution) on the fresh sediment core (Rein and Sirocko, 2002; Trachsel et al., 2010). Two well-established spectral indices, Reflectance $570 \mathrm{~nm} /$ Reflectance $_{630 \mathrm{~nm}}\left(R_{570} / R_{630}\right)$ and Relative Absorption Band Depth 660-670 nm (RABD $660 ; 670)$ were used. $R_{570} / R_{630}$ is indicative of the clay mineral concentration in lake and marine sediments (mainly illite, chlorite and biotite; Rein et al., 2005, USGS Spectral Library; Trachsel et al., 2010). The same authors use the index $R_{570} / R_{630}$ also as an approximation for the "lithogenic content" of lake sediments. $\operatorname{RABD}_{660 ; 670}$ is indicative of total chlorins (diagenetic products of chlorophyll $a$; Rein and Sirocko, 2002; Rein et al., 2005; von Gunten et al., 2009b).

Biogenic silica (bSi) was extracted by alkaline leaching with $1 \mathrm{M} \mathrm{NaOH}$ at $90^{\circ} \mathrm{C}$ for three hours (Mortlock and Fröhlich, 1989) after the removal of organic matter (30\% $\mathrm{H}_{2} \mathrm{O}_{2}$ ) and measured using ICP-OES (inductively coupled plasma optical emission spectrometry). Since the Al/Si ratios of the leachate were very low $\left({ }^{\mathrm{wt}} \mathrm{Al}:{ }^{\mathrm{wt}} \mathrm{Si}\right.$ ranging from $1: 16$ to $1: 57$ ) no correction was applied for lithogenic amorphous silica. Total carbon and nitrogen were measured using a Vario Macro Elemental Analyzer on 100-200 mg of dry sediment. Loss on ignition was carried out on $500 \mathrm{mg}$ of dry sediment in a muffle furnace at $550{ }^{\circ} \mathrm{C}$ for the duration of $2.5 \mathrm{~h}$ (Heiri et al., 2001). Tests with warm $10 \% \mathrm{HCl}$ were negative, suggesting that no inorganic carbon was present in the sediment. Hence total $\mathrm{C}$ can be used as an approximation for $\mathrm{C}_{\text {org }}$.

Gamma-decay counts of ${ }^{210} \mathrm{~Pb},{ }^{226} \mathrm{Ra}$ and ${ }^{137} \mathrm{Cs}$ were measured for more than $20 \mathrm{~h}$ using Canberra low background well-type $\mathrm{GeLi}$ detectors. Unsupported ${ }^{210} \mathrm{~Pb}$ was calculated from the ${ }^{226} \mathrm{Ra}$ activity using the level-by-level method (Appleby, 2001). To convert ${ }^{210} \mathrm{~Pb}_{\text {unsupported }}$ activity profiles into numerical ages (AD) the sediment isotope tomography (SIT) model (Liu et al., 1991) was used, which has the advantage that it calculates ages without a priori assumptions about the sedimentation and the ${ }^{210} \mathrm{~Pb}$ flux terms (von Gunten et al., 2009a; Tylmann et al., 2013). Four chronostratigraphic markers were available: (i) the ${ }^{137} \mathrm{Cs}$ peak at AD 1963/64, (ii) the initial increase of ${ }^{137} \mathrm{Cs}$ around $\mathrm{AD} 1948-1952$, (iii) an SCP profile fitted to regional independently dated SCP profiles (von Gunten et al., 2009a) and (iv) the dam building at $1885 \pm 5 \mathrm{yr}$ at $20.2 \mathrm{~cm} \pm 1 \mathrm{~cm}$ depth. The ${ }^{137} \mathrm{Cs}$ peak AD 1963/1964 was used to constrain the SIT model, whereas the other chronostratigraphic markers were used for independent validation of the age model.

The lower part of the age-depth curve was based on four ${ }^{14} \mathrm{C}$ dates (Table 1 ) on bulk organic sediments, and was combined with the SIT model using a mixed-effect regression model assuming constant variance (Heegaard et al., 2005). Here we introduced the timing of dam building as an additional data point. All radiocarbon dates were calibrated using the ShCal04 Southern Hemisphere calibration curve (McCormac et al., 2004).
Table 1. Radiocarbon dates and calibrated ages.

\begin{tabular}{lllll}
\hline $\begin{array}{l}\text { Sediment } \\
\text { depth }(\mathrm{cm})\end{array}$ & Material & ${ }^{14} \mathrm{C} \mathrm{yr} \mathrm{BP} \pm 1 \sigma$ & $\begin{array}{l}\text { min-max age } \\
\text { cal. BP }\end{array}$ & Lab. code \\
\hline $17.75^{*}$ & Bulk org. matter & $1315 \pm 30$ & $1174-1262$ & Poz-26625 \\
29.75 & Bulk org. matter & $1135 \pm 30$ & $957-1002$ & Poz-26672 \\
45.25 & Bulk org. matter & $1990 \pm 30$ & $1862-1903$ & Poz-26673 \\
58.25 & Bulk org. matter & $2465 \pm 30$ & $2353-2472$ & Poz-20057 \\
81.25 & Bulk org. matter & $3030 \pm 35$ & $3076-3216$ & Poz-20056 \\
\hline
\end{tabular}

* This sample was excluded from the final age-depth model since it indicates erroneously old ages in comparison to all other chronological markers.

\subsection{Meteorological data}

Meteorological data in this region are mostly located at low elevations near the coast and in the Central Valley. Most of these time series are short and discontinuous. The longest and most complete temperature record is available from $\mathrm{Pu}-$ dahuel/Santiago $\left(33^{\circ} 38^{\prime} \mathrm{S}, 70^{\circ} 78^{\prime} \mathrm{W}, 504 \mathrm{~m}\right)$ covering the period AD 1901-present (AD 1986-1990 missing). High altitude station data are very scarce and incomplete. Most valuable is the temperature record from the high-altitude Cristo Redentor meteorological station $\left(32^{\circ} 50^{\prime} \mathrm{S}, 70^{\circ} 05^{\prime} \mathrm{W}\right.$, $3109 \mathrm{~m}$ ) covering the period AD 1941-1984 with several years and monthly data missing. In absence of long local meteorological data series the reanalysis temperature data (HadCRU TS3, extracted for the $0.5^{\circ} \times 0.5^{\circ}$ grid cell representing the study area; Mitchell and Jones, 2005) had to be used for the proxy - climate calibration. This procedure has been successfully applied and the representativeness of the reanalysis temperature data has been tested in other remote areas in Central Chile (von Gunten et al., 2012). For the calibration and reconstruction the temperature anomalies were calculated with reference to the 20th century mean.

\subsection{Statistical analyses}

All statistical analyses were carried out using $\mathrm{R}$ ( $\mathrm{R}$ development core team, 2012). To assess the influence of dam building in the lake, two types of hierarchical cluster analyses (CONISS; Grimm, 1987, Conslink; Birks and Gordon, 1985) were carried out to test whether any significant splits in the dataset coincided with the estimated timing of dam building. The number of significant splits was assessed by comparison to the broken stick model (BSTICK; Bennett, 1996). Calculations were carried out using the R-package RIOJA (Juggins, 2009).

The proxy - climate calibration followed the procedure described by von Gunten et al. (2012). To allow for a comparison of meteorological data with proxy data, the VISRS proxy data ( $2 \mathrm{~mm}$ resolution) were regularized to annual resolution. To assess the sensitivity of the VIS-RS proxies to climatic parameters in the calibration period (AD 19012006), Pearson's correlation coefficients were calculated between each proxy time series $\left(R_{570} / R_{630}\right.$ and $\left.\mathrm{RABD}_{660 ; 670}\right)$ and 144 different combinations of (consecutive) monthly 
mean temperatures, allowing for a lagged response of up to 2 yr (see e.g. De Jong and Kamenik, 2011; Saunders et al., 2013). The significance values of all correlation coefficients were corrected for serial autocorrelation $\left(P_{\text {aut }}\right.$; Bayley and Hammersley, 1946) and multiple testing $\left(P_{\text {adj }}\right.$; Benjamini and Hochberg, 1995). The same analyses were carried out for monthly precipitation. For combinations of proxy and meteodata with high and significant correlation coefficients, trend tests were carried out (Spearman's Rank correlation) and $R$ and $p_{\text {adj }}$ values were also calculated for linearly detrended data.

To take into account dating uncertainties and sediment bioturbation during the calibration period, the correlation coefficients and adjusted $p$ values were calculated for $3 \mathrm{yr}$ and $5 \mathrm{yr}$ filtered reanalysis and proxy data (De Jong and Kamenik, 2011; von Gunten et al., 2012). The performance of the inverse linear regression model (reduction of error RE and coefficient of efficiency $\mathrm{CE}$ ) was assessed by splitting the calibration period into a calibration (AD 1960-2004) and validation (AD 1901-1960) period. Model residuals were checked for homoscedasticity, normality of error distribution and non-constant error variance. The model error (root mean square error of prediction: RMSEP) was calculated by bootstrapping, jack-knifing and ten-fold cross validation. Linear model building and performance testing was performed using the R add-on packages IPRED (Peters and Hothorn, 2011), ANALOGUE (Simpson and Oksanen, 2009), VEGAN (Oksanen et al., 2011), PASTECS (Ibanez et al., 2009) and GDATA (Warnes, 2010).

\section{Results}

\subsection{Age model}

The sediments are composed of massive, organic $\left(C_{\text {org }} 8-\right.$ $20 \%$ ), dark brown silt. The organic matter is mostly amorphous with decomposed macrofossils of aquatic plants. At $20 \mathrm{~cm}$ sediment depth, a light brown ca. $1 \mathrm{~cm}$-thick layer is present which was assigned to dam building around

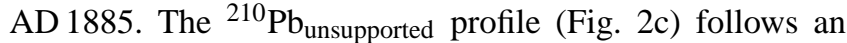
overall pattern of exponential decay from a relatively low initial activity of ca. $150 \mathrm{~Bq} \mathrm{~kg}^{-1}$. Very low activity values were measured around $20 \mathrm{~cm}$ sediment depth. ${ }^{137} \mathrm{Cs}$ activities (Fig. 2c) show increased values at a sediment depth of $8.3 \mathrm{~cm}$ and peak values at $5.7 \mathrm{~cm}$. The first SCPs were found around $18.2 \mathrm{~cm}$ sediment depth and a marked SCP increase occurred at $5.5 \mathrm{~cm}$ depth (Fig. $2 \mathrm{~d}$ ).

The SIT age-depth model (Fig. 2b) suggests uniform sedimentation rates for the top $20 \mathrm{~cm}$. The dating error for the most recent period (AD 1950-2006) is only 1-3 yr, whereas from AD 1900-1950 the chronological uncertainty is +1 to $-9 \mathrm{yr}$. The SIT age model was validated by comparison to the independent chronostratigraphic ${ }^{137} \mathrm{Cs}$ marker (increasing activity at $8.3 \mathrm{~cm}$ sediment depth, AD 1948-1952), the
SCP profile (18.2 cm, AD 1880-1900) and the light band at $20.2 \pm 1 \mathrm{~cm}$ sediment depth (assigned to the artificial dam building around $\mathrm{AD}$ 1885). The age-depth model for the entire sediment core (Fig. 2a) shows that sedimentation rates were lower and dating uncertainties were larger (50-150 yr) prior to dam building. The sediment core covers the period from ca. $3000 \mathrm{yr}$ ago until present.

\subsection{Sediment composition and spectral reflectance properties}

Figure 3 shows the multi-proxy data set for core CHEP0603 and the ash content measured on parallel core CHEP 06/04. RABD $660 ; 670$ (indicative of total chlorin as an approximation of organic matter) shows strong variability in the sub-cm to decimeter-range with a constant mean value (no trend) below $20 \mathrm{~cm}$ sediment depth and a decreasing trend in the uppermost $18 \mathrm{~cm} . R_{570} / R_{630}$ (indicative of clay minerals as an approximation of lithogenic matter) shows variability in a broad range of spatial (temporal) scales and is positively correlated $(R=0.65, p<0.05)$ with the ash content (1-LOI 550$)$ and negatively correlated with $\mathrm{bSi}(R=-0.46$, $p<0.05)$. Total organic carbon in the uppermost $20 \mathrm{~cm}$ of sediment shows a strong decrease towards the sediment surface. ${ }^{\mathrm{wt}} \mathrm{C} /{ }^{\mathrm{wt}} \mathrm{N}$ rations are constant around a value of 9 , suggesting mainly aquatic sources of sedimentary organic matter.

To assess the possible influence of the dam construction, cluster analysis was carried out on the VIS-RS dataset. CONISS analysis and comparison to the BSTICK model yielded ten significant splits, none of which coincided with the dam building phase (at $20.2 \mathrm{~cm} \pm 1 \mathrm{~cm}$; gray horizontal shading in Fig. 3). The five most significant splits are shown in Figs. 3a, b.

\subsection{Temperature - proxy data comparison}

Figure 4 a shows that the pattern of $R_{570} / R_{630}$ closely matches the NDJF temperature data from the high-altitude meteorological station Cristo Redentor. The correlation tests between the two VIS-RS proxies and climate reanalysis data (monthly mean temperature and precipitation from AD 1901-2006) showed that $R_{570} / R_{630}$ (lithogenic content) and mean November-February (NDJF) austral summer temperatures were strongly and significantly correlated for unfiltered $\left(R=-0.49, p_{\text {adj }}<0.001\right), 3 \mathrm{yr}$-filtered $(R=-0.63$, $\left.p_{\text {adj }}=0.01\right)($ Fig. $4 \mathrm{~b}-\mathrm{c})$ and $5 \mathrm{yr}$-filtered $\left(R=-0.66, p_{\text {adj }}=\right.$ 0.05 ) data. Since the $5 \mathrm{yr}$-filtered data result in only a small increase in the correlation coefficient, the $3 \mathrm{yr}$-filtered model was used for subsequent reconstructions. Both the meteorological data and the proxy data showed significant trends during the calibration period. Therefore, the correlation coefficient for detrended data was also calculated ( $3 \mathrm{yr}$-filtered, detrended data $R=-0.47, p_{\text {adj }}=0.045$ ), yielding a lower but still significant correlation. Correlations with other seasons 

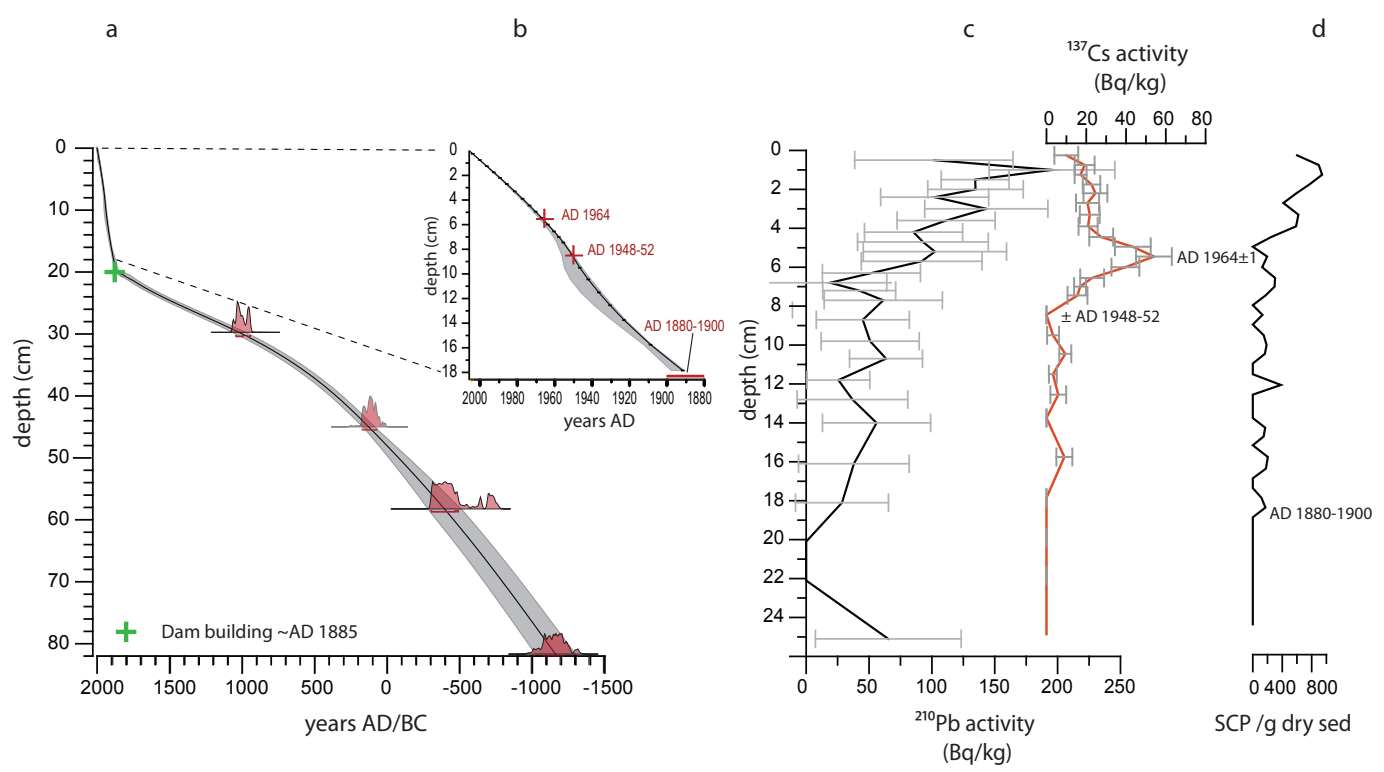

Fig. 2. (a) Full age depth model, based on radiocarbon dates for the lower part (probability distribution of each sample shown), the dam building phase around $20.2 \pm 1 \mathrm{~cm}$ at AD $1885 \pm 5 \mathrm{yr}$, and the SIT model for the upper part. The SIT model and associated errors are shown in detail in (b). The SIT model was based on measured ${ }^{210} \mathrm{~Pb}$ activity (shown in c) and constrained by the clear ${ }^{137} \mathrm{Cs}$ peak at $5.7 \mathrm{~cm}$ depth. The additional, independent marker horizons derived from the onset of ${ }^{137}$ Cs activity $(8.2 \mathrm{~cm})(\mathbf{c})$ and the first appearance of Spheroidal Carbonaceous Particles $(18.2 \mathrm{~cm})$ are also shown (d).

or with precipitation were not significant, and no significant correlations were found for $\mathrm{RABD}_{660 ; 670}$ with any of the climatic data. The comparisons in Fig. 4 show that sub- to multi-decadal climate variability is very well reproduced by the sediment proxy (Fig. 4 blue line), whereas annual climate variability is poorly represented.

\subsection{Calibration model statistics}

NDJF temperatures were predicted from the $3 \mathrm{yr}$-filtered $R_{570} / R_{630}$ data using inverse linear regression, thus temperature data were used to predict the proxy data during the calibration period (AD 1901-2006). The split-period validation revealed a high reduction of error $(\mathrm{RE}=0.53)$ and a positive coefficient of efficiency $(\mathrm{CE}=0.42)$. The model $\mathrm{RMSEP}_{(\text {jack,boot, } \mathrm{x}-\text { fold) }}$ for the full reconstruction was $0.33-$ $0.34{ }^{\circ} \mathrm{C}$, which represents $11 \%$ of the reconstructed temperature range. Regression error diagnostics show that there were no outliers in the residuals, residuals were normally distributed and error variance was constant. No residuals were identified with an undue influence on model performance (leverage). However, the residuals were temporally autocorrelated (up to $6 \mathrm{yr}$ ), resulting from data filtering as well as bioturbation of the sediments.

Figure $5 \mathrm{c}-\mathrm{d}$ show the measured NDJF temperature anomalies (relative to the 20th century mean) during the calibration period (in red) and the proxy-based full NDJF temperature reconstruction with the $95 \%$ confidence intervals (bootstrapped error estimates) for the reconstruction.
The grey shaded areas denote temperature reconstructions beyond the temperature range of the calibration period. Temperatures during these periods should be interpreted in a qualitative manner only. The reconstruction shows relatively high summer temperatures around 250 BC, AD 600-800, $\mathrm{AD} 1600-1800$ and in the 20th century. The $R_{570} / R_{630}$ proxy reproduces the peak warmth from AD 1940-1970 as observed in reanalysis data for this area. Lower temperatures were reconstructed around $900 \mathrm{BC}, 100 \mathrm{BC}$, AD 900-1200, AD 1550, and AD 1800-1850.

\section{Discussion}

\subsection{Model performance and data quality}

For the comparison of proxy data to meteorological data (calibration in time), a reliable age-depth model is essential in particular for the calibration period (here AD 1901-2006). Although the measurement error in the individual $\mathrm{Pb}$ decay counts is large (Fig. 2c) due to the overall low activity of unsupported ${ }^{210} \mathrm{~Pb}$, the final age uncertainty in the SIT model is relatively small since the clear ${ }^{137} \mathrm{Cs}$ peak measured in the sediments could be used to constrain the model. The additional chronostratigraphic markers independently validate the SIT model, resulting in a reliable, precise age-depth model for the top $20 \mathrm{~cm}$ of the core. Below the dam building layer at ca. $20 \mathrm{~cm}$ depth, the age uncertainty is larger (up to $100-150 \mathrm{yr}$ ) due to the uncertainties in the radiocarbon chronology, the smaller number of dated samples and 


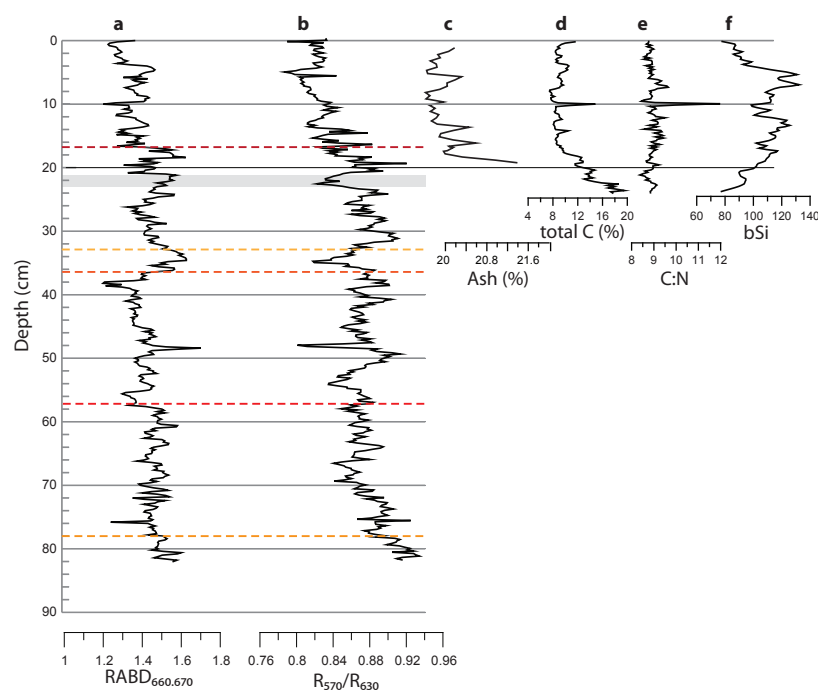

Fig. 3. This figure shows the multi-proxy dataset for core CHEP 06/03 and the ash content measured on parallel core CHEP06/04. The proxies derived from spectral scanning of the cores in the visible light range are (a) $\mathrm{RABD}_{660 / 670}$, which is known to represent chlorins (chlorophyll decay products) in the sediments, and (b) $R_{570} / R_{630}$, a proxy for the mineral (clay) content of the core. The latter is, as expected, significantly correlated to the ash content (LOI-1) shown in (c). The total amount of carbon (d), C: N ratios (e) and total biogenic Silica (f) are also shown for the upper part of the sediment core. The grey horizontal bar indicates the level of the light-colored sediment layer which was interpreted as the dam building phase. Colored horizontal lines in (a) and (b) reflect the five most significant splits (clusters) of the VIS-RS dataset.

the absence of chronostratigraphic markers. This uncertainty has to be kept in mind when comparing this reconstruction to other records.

For calibration the re-analysis data from Mitchell and Jones (2005) were used. The reliability of re-analysis data depends on the input data from meteorological stations, which, in the case of central Chile, are often discontinuous and strongly biased towards low elevation (Villalba et al., 2003). As mentioned in the introduction, recent temperature trends along the Chilean coastline were found to diverge from high altitude temperature patterns and it is therefore debated how well low-altitude station data represent high-altitude temperature processes. Although these shortcomings are relevant in particular for this high-altitude study, the re-analysis data are currently the only long, continuous time series available for the high Andes. The good match between $R_{570} / R_{630}$ and the few available summer temperature data from the highaltitude Cristo Redentor meteorological station (Fig. 4a) is important in this context since this comparison is not hampered by an altitudinal bias.

In addition, the reliability of the reconstruction depends on the quality of the proxy-climate calibration and the associated errors. In this study, the correlation between $R_{570} / R_{630}$

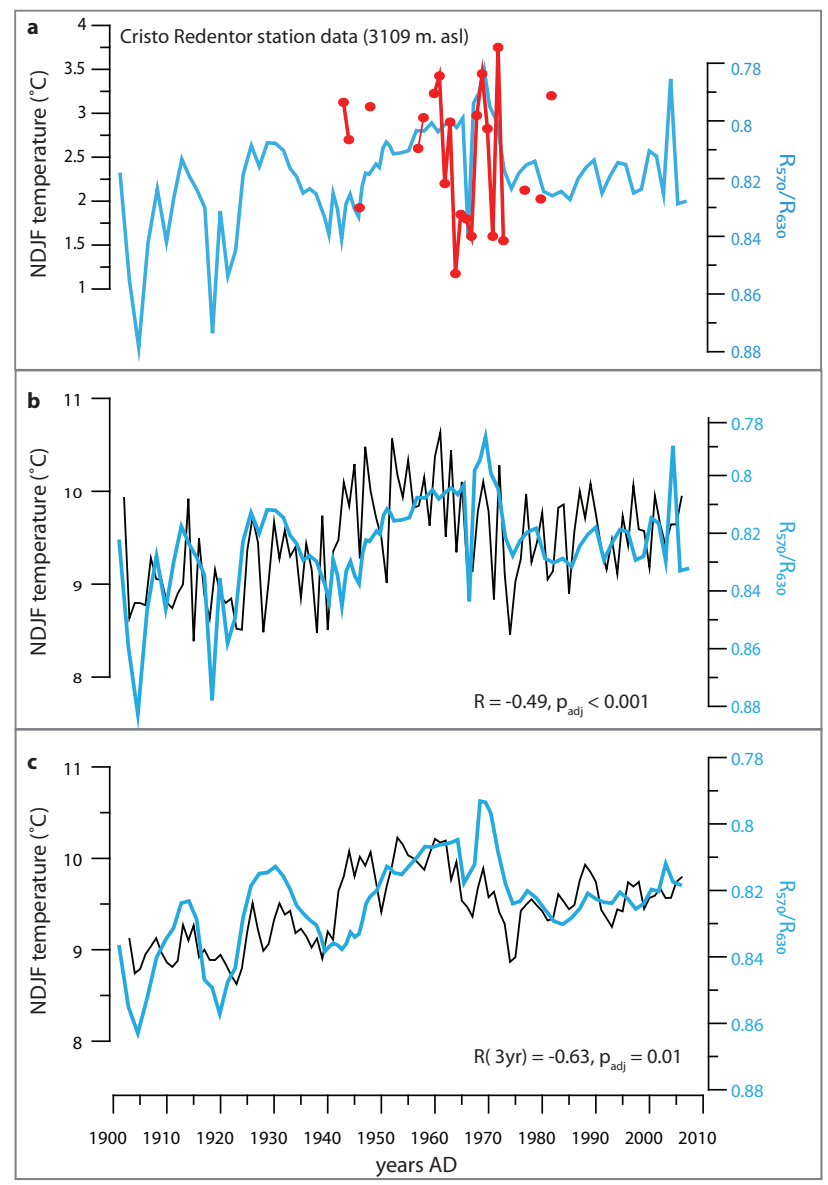

Fig. 4. This figure shows the data used for the calibration model. (a) compares the measured lithogenic content in the core $\left(R_{570} / R_{630}\right)$ to meteorological station data (NDJF temperatures) from high altitude Cristo Redentor, for which only few complete NDJF mean temperature data points are available. However, the good match confirms the interpretation of the lithogenic content as a strong proxy for summer temperatures at high altitudes. The final calibration model was based on the high and significant correlation between the lithogenic content of the core and NDJF temperatures from reanalysis data (Mitchell and Jones, 2005). These are shown in (b) for unfiltered, and (c) 3 yr-filtered data.

and NDJF temperatures is robust and is also significant for linearly detrended data. This is highly relevant since it indicates that the proxy-climate correlation is not solely controlled by long-term trends (which may be driven by a range of environmental variables other than temperature, e.g. air pollution, land use changes etc.), but also by short-term variability in measured temperatures. In addition, the regression model performance values show that overall, model performance was good, with a high RE, positive CE and low RMSEP in comparison to the reconstructed temperature range ( $11 \%$ of the reconstructed temperature range). Unfortunately, back in time the temperature reconstruction frequently exceeds the temperature range of the calibration 


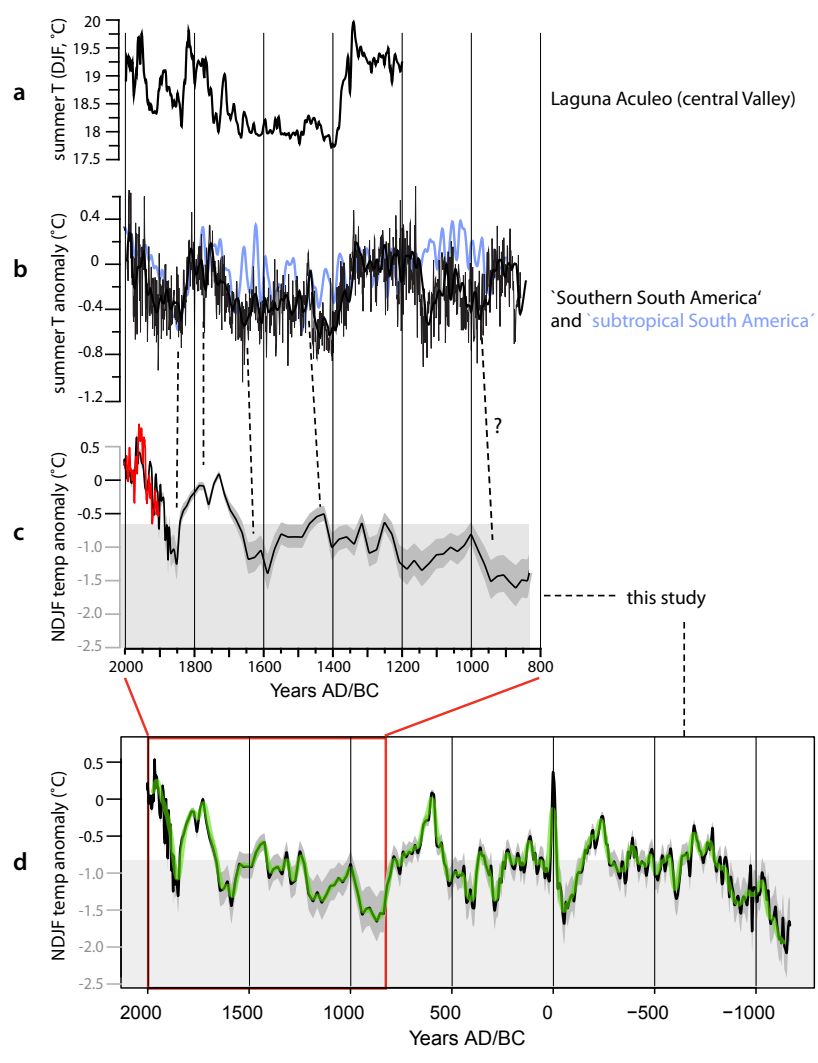

Fig. 5. Comparison of the few available summer temperature reconstructions for this region, showing (a) DJF temperatures reconstructed from spectral reflectance indices measured on a sediment core from Laguna Aculeo (Central Valley, $34^{\circ} \mathrm{S}, 515 \mathrm{~m}$ a.s.1.; Von Gunten et al., 2009b), (b) DJF temperature anomalies for southern South America, which was based on climate field reconstructions using a range of meteorological, documentary and proxy data, including the record shown in (a) (Neukom et al., 2011). The blue line in (b) shows the regional reconstruction from the same authors for subtropical South America. The NDJF temperature reconstruction (black line) from Laguna Chepical back to AD 800 is shown in (c) together with the bootstrapped model errors (grey envelope). The reanalysis NDJF temperatures are shown in red (Mitchell and Jones, 2005). In (d) the full reconstruction is shown, together with the $50 \mathrm{yr}$-filtered data (green line). Because of the absolute temperature offset between the reanalysis and meteorological data at this location (compare $y$ axes in Fig. $4 \mathrm{a}$ and b, and see Fig. 1b), the final reconstruction was calculated as temperature anomalies (in ${ }^{\circ} \mathrm{C}$ ) in comparison to the 19th century mean. The grey shaded bars in (c) and (d) indicate reconstructed temperature values that lie outside the temperature range of the calibration period, implying that these data should be interpreted in a qualitative manner only.

period. Values outside the calibration range are thus based on linear extrapolation, which might be unrealistic in natural environmental processes. Values outside this range (indicated by shaded areas in Fig. 5) as well as error estimates should therefore be interpreted in a qualitative manner only.
A mechanism is required that explains the increase of the fine lithogenic content of the core during cool summers and vice versa. Rein et al. (2005) introduced the spectral reflectance ratio $R_{570} / R_{630}$ as a proxy for continental runoff related to strong El Niño rainfall events, as indicated by the increased presence of (soil) clay minerals in a marine sediment core of the Peruvian coast. Therefore, in this study we tested whether the spectral ratio $R_{570} / R_{630}$ also represented the lithogenic content in Laguna Chepical. The significant correlation between $R_{570} / R_{630}$ and the ash content (Fig. 3c) confirmed the interpretation of $R_{570} / R_{630}$ as a proxy for the lithogenic content of the sediments.

We argue that in Laguna Chepical, clay settling is controlled (prevented) by wind-induced mixing. During the open water season and in the presence of strong winds in the high mountain setting, turbulent water mixing occurs frequently throughout the entire water column, which effectively leads to fine particles being "trapped" in the water body. Outflow from the lake during snowmelt and in early summer removes these particles from the lake system. Therefore, the longer the ice-covered period and the later the timing of ice-breakup (and subsequent mixing) the more fine sediment particles will settle.

Theoretically, the timing of ice break-up and the duration of the ice-free period are determined by mean air temperatures in the warm season, from just prior to break-up until ice is formed again (November-March). This is highly similar to the found correlation to NDJF temperatures. Although other environmental parameters (wind speed and direction (fetch)) also influence the formation of ice on lakes (Livingstone, 1997), these are thought to be of minor importance for this very small lake. Other parameters that may influence the duration of ice cover are e.g. winter precipitation (a snow cover on ice may delay melting), winter temperatures (cooler temperatures lead to thicker ice) and spring precipitation (rainfall on ice enhances melting). However, none of these climatic parameters was significantly correlated to $R_{570} / R_{630}$. Thus, we propose that the sediments' fine lithogenic content is controlled by the duration of the ice-free period, which is governed by NDJF temperatures.

An additional, potentially important environmental variable was the construction of the earth dam in AD 1885. However, as indicated by cluster analyses, the construction of a low (ca. $2 \mathrm{~m}$ ) earth dam and the subsequent relatively small increase in maximum lake depth did not significantly affect most of the sediment properties measured with VIS-RS scanning and had no influence on the $R_{570} / R_{630}$ values. Therefore, the reconstruction of summer temperatures based on calibration-in-time, which was developed for the period after dam building, is also valid back in time.

Finally, it is important to note that the reconstruction presented in this study is based on the assumption that the lithogenic content depended entirely on NDJF temperatures throughout the reconstruction period. Obviously, this assumption introduces an unknown amount of uncertainty to 
the reconstruction, since changes in environmental factors and lake sediment responses cannot be ruled out, in particular over such long time periods. However, this basic assumption is part of all proxy-based environmental reconstructions, regardless whether calibration-in-time (von Gunten et al., 2012) or Transfer Functions (calibration-in-space) are used (Juggins, 2013). Additional reconstructions from this high altitude region are required to verify the patterns reconstructed in this study, in particular further back in time.

\subsection{High Andean summer temperatures during the past $3000 \mathrm{yr}$}

Figure 5 shows the temperature reconstruction from Laguna Chepical in comparison to the summer temperature (DJF) reconstructions from lowland Laguna Aculeo (von Gunten et al., 2009b) and southern South America (Neukom et al., 2011; updated in PAGES 2k Consortium, 2013; this reconstruction includes the data from Laguna Aculeo shown in Fig. 5a). Back to AD 1450, these reconstructions have several important features in common. All records show the 20th century warming and in particular, the warm period between ca. AD 1940-1970. For Laguna Chepical, the reconstructed warmth during these decades is likely the warmest phase of the past $3000 \mathrm{yr}$, since it exceeds all previous warm phases whether looking at raw, $30 \mathrm{yr}$ or $50 \mathrm{yr}$-filtered data (Fig. 5d). This finding is in agreement with the large scale temperature patterns compiled by the PAGES $2 \mathrm{k}$ Consortium (2013), who concluded that recent warmth exceeds temperatures during the past $1400 \mathrm{yr}$ on all continents except Antarctica.

After ca. AD 1450 overall cooler summer temperatures were reconstructed in most records shown in Fig. 5, which broadly coincides with the onset of the "Little Ice Age" (LIA) as described from many sites and proxies along the Northern Hemisphere Atlantic seaboard. As illustrated in the PAGES 2k Consortium (2013) data compilation for each continent, the extent and timing of this cool phase varied substantially globally as well as regionally. In South America the cool phase falls between ca. AD 1400-1900, whereas in our reconstruction cooling started prior to that. However, one of the most prominent features in the reconstructions shown in Fig. 5 is the interruption of the LIA cold phase by pronounced warmth during the 18th century. In Neukom et al. (2011), this warm phase was shown to be consistent from northern Patagonia to the subtropics of South America. The independent reconstruction based on tree ring widths by Villalba et al. (2003) also shows 18th century warmth for northern Patagonia but not for southern Patagonia. The reconstruction presented here provides additional evidence for the occurrence of this warm phase in the high Andes of central Chile. Its causes are, however, currently not known, and the large (continental) scale temperature reconstructions compiled by the PAGES 2k Consortium (2013) show that the 18th century was not consistently warm outside South America. Thus, back to ca. AD 1450, the three reconstructions compare remarkably well, in particular when taking into account the different spatial scales, altitude and proxy-data used in each study. These similarities confirm the reliability of the methods applied in this study and the quality of the reconstruction. Moreover, this finding indicates highly similar long-term temperature evolution at high Andean and low altitude (Central Valley and Patagonia) sites.

However, prior to AD 1450 the reconstructed temperature patterns shown in Fig. 5 display clear differences. For example, in contrast to the lowland Laguna Aculeo record and the SSA reconstruction in Fig. 5a and b, the temperature reconstruction from Laguna Chepical does not indicate warm temperatures prior to $\mathrm{AD} 1450$, equivalent to the so-called Medieval Climate Anomaly (MCA). Instead, cool temperatures prevailed from ca. AD 800-AD 1900, interrupted by the previously mentioned 18 th century warm phase. However, this finding is comparable to the reconstructed subtropical temperature patterns in Neukom et al. (2011), shown in Fig. 5b (blue line), where a clear MCA is also absent. Similarly, during the MCA the Quellcaya ice core record (Thompson et al., 2013) does not contain ice melting layers or $\delta^{18} \mathrm{O}$ smoothing associated with percolating meltwater, whereas these characteristics are typical for the Quelcaya ice cap since AD 1991, when glacier retreat started.

Shortly before AD 1000 a particularly strong cold anomaly was reconstructed for the Chepical region. This cool phase (AD 850-950) coincides with parts of the cool phase recorded in the southern South American PAGES 2k Consortium (2013) reconstruction from ca. AD 900-1050. Prior to $\mathrm{AD} 800$ no other high-resolution temperature records are available for comparison. The Chepical record shows relatively stable, warm conditions between $700 \mathrm{BC}$ and $\mathrm{AD} 800$, whereas prior to $800 \mathrm{BC}$ conditions were cool. This cool phase coincides roughly $( \pm 150 \mathrm{yr})$ with glacier advances in the Valle Encierro in the central Chilean Andes $\left(29^{\circ} \mathrm{S}\right.$; Grosjean et al., 1998), as well as with the timing of glacier advances and cool/more humid conditions that have been recorded in a range of different sites and proxy records worldwide (e.g. Van Geel et al., 1996; Mayewski et al., 2004; Wanner et al., 2008).

\section{Conclusions}

The summer temperature reconstruction presented in this study provides important insight into the late Holocene evolution of temperature in the central Chilean high Andes. The reconstruction from Laguna Chepical (3050 m a.s.l.) is currently the only study that represents summer temperatures at high altitudes in this region, since other high altitude proxy records primarily respond to changes in precipitation (glacial cores, tree rings) or are based on low altitude sites. Careful dating and model testing during the calibration period (AD 1901-2006) have resulted in a statistically robust temperature-proxy calibration model. This model was 
based on the high and significant correlation $(R=-0.63$, $p_{\text {adj }}=0.01$ ) between NDJF temperatures and the spectral reflectance ratio representing the lithogenic (clay) content of the core $\left(R_{570} / R_{630}\right)$. As a mechanism, we propose that the clay content in the sediments is controlled by the duration of the ice-free season (and hence spring-summer temperatures) since clay settling can only occur during very calm (ice-covered) conditions.

This climate-proxy calibration model was then applied downcore, yielding a summer temperature reconstruction back to ca. 1000 BC. From AD 1400 to present, the Chepical temperature reconstruction compares remarkably well with other (low altitude) records from this region. The reconstruction shows that recent decades (AD 1940-1970) were likely the warmest of the past $3000 \mathrm{yr}$. Interestingly, the Chepical reconstruction shows a pronounced warm period around the 18th century AD, which has been observed in a number of reconstructions from this part of South America but remains enigmatic. Overall, the Little Ice Age was characterized by cooler temperatures in this region. The Laguna Chepical record does not show a warm Medieval Climate Anomaly, which is in agreement with records representing the subtropics of South America. Other records from southern South America (Patagonia) and the central Valley of Chile, however, do show an MCA warm phase. Relatively cool conditions were reconstructed around AD 900 and prior to $800 \mathrm{BC}$. This latter cool phase may represent the wellknown cool/humid period that has been observed in a number of records worldwide around $700 \mathrm{BC}$ ( $2650 \mathrm{cal}$. yr. BP).

The reconstruction presented here fills an important gap in our knowledge on high altitude temperature evolution on the central Chilean Andes. Although model performance is good and the reconstruction compares very well to other studies in particular after AD 1450, additional high altitude reconstructions are required to overcome the remaining, possibly large uncertainties in proxy-based reconstructions. Furthermore, detailed comparisons to climate model data would shed light on the climatic mechanisms causing the observed temperature patterns. Such studies are planned for the near future.

Acknowledgements. We would like to thank M. Espinoza from DIFROL for permissions to carry out fieldwork in Chile. We would also like to thank the two reviewers for their helpful comments and suggestions to improve the manuscript. Laboratory assistance by S. Hagnauer was greatly appreciated. C. Butz helped drawing Fig. 1. Total biogenic silica was measured at the Paul Scherrer Institute (Villigen) and gamma decay counts of ${ }^{210} \mathrm{~Pb},{ }^{137} \mathrm{Cs}$ and ${ }^{226} \mathrm{Ra}$ were measured at EAWAG, Dübendorf. Radiocarbon ages were determined at the Poznan Radiocarbon Laboratory. This project was funded by the Swiss National Science Foundation (Ambizione grant to RdJ, PZ00P2_131797 and grants NF 200020121869 and 200021-107598 to MG) and the Chilean Swiss Joint Research Programme No. CJRP-1001.

Edited by: J. Guiot

\section{References}

Aceituno, P.: On the functioning of the Southern Oscillation in the South American Sector. Part 1; surface climate, Mon. Weather. Rev, 116, 505-524, 1988.

Appleby, P. G.: Chronostratigraphic techniques in recent sediments, in: Tracking environmental change using lake sediments Volume 1: basin analysis, coring, and chronological techniques, edited by: Last, W. M. and Smol, J. P., Kluwer Academic, 171-203, 2001.

Bayley, G. V. and Hammersley, J. M.: The "effective" number of independent observations in an autocorrelated time series, Supplement, J. R. Stat. Soc., 8, 184-197, 1946.

Benjamini, Y. and Hochberg, Y.: Controlling the false discovery rate: a practical and powerful approach to multiple testing, J. R. Stat. Soc. B, 57, 289-300, 1995.

Bennett, K. D.: Determination of the number of zones in a biostratigraphical sequence, New Phytol., 132, 155-170, 1996.

Birks, H. J. B. and Gordon, A. D. (Eds.): Numerical Methods in Quaternary Pollen Analysis, Academic Press, London, 1985.

Boninsegna, J. A., Argollo, J., Aravena, J. C., Barichivich, J., Christie, D., Ferrero, M. E., Lara, A., Le Quesne, C., Luckman, B. H., Masiokas, M., Morales, M., Oliveira, J. M., Roig, F., Srur, A., and Villalba, R.: Dendroclimatological reconstructions in South America: A review, Palaeogeogr. Palaeoclim., 281, 210-228, 2009.

Bradley, R. S., Vuille, M., Diaz, H. F., and Vergara, W.: Threats to Water Supplies in the Tropical Andes, Science, 312, 1755-1756, 2006.

De Jong, R. and Kamenik, C.: Validation of a chrysophyte stomatocyst-based cold-season climate reconstruction from high-Alpine Lake Silvaplana, Switzerland, J. Quaternary Sci., 26, 268-275, doi:10.1002/jqs.1451, 2011.

Diaz, H. F., Grosjean, M., and Graumlich, L.: Climate variability and change in high elevation regions: past, present and future, Clim. Change, 59, 1-4, 2003.

Falvey, M. and Garreaud, R.: Regional cooling in a warming world: Recent temperature trends in the southeast Pacific and along the west coast of subtropical South America (1979-2006), J. Geophys. Res., 114, D04102, doi:10.1029/2008JD010519, 2009.

Garreaud, R. D., Vuille, M., Compagnucci, R., and Marengo, J.: Present-day South American climate, Palaeogeogr. Palaeoclim., 281, 180-195, 2009.

Grimm, E. C.: CONISS: a FORTRAN 77 program for stratigraphically constrained cluster analysis by the method of incremental sum of squares, Comp. Geosci., 13, 13-35, 1987.

Grosjean, M., Geyh, M. A., Messerli, B., Schreier, H., and Veit, H.: A late-Holocene $(2600 \mathrm{BP})$ glacial advance in the south-central Andes (29 $\mathrm{S})$, northern Chile, Holocene, 8, 473-479, 1998.

Heegaard, E., Birks, H. J. B., and Telford, R. J.: Relationships between calibrated ages and depth in stratigraphical sequences: an estimation procedure by mixed-effect regression, Holocene, 15, 612-618, doi:10.1191/0959683605h1836rr, 2005.

Heiri, O., Lotter, A. F., and Lemcke, G.: Loss on ignition as a method for estimating organic and carbonate content in sediments: reproducibility and comparability of results, J. Paleolimnol., 25, 101-110, 2001.

Ibanez, F., Grosjean, P., and Etienne, M.: Pastecs: Package for Analysis of Space-Time Ecological Series, available at: http://CRAN. R-project.org/package=pastecs (last access: 4 March 2013), 
2009.

Juggins, S.: Rioja: an R package for the analysis of quaternary science data, available at: http://www.staff.ncl.ac.uk/staff/stephen. juggins/ (last access: 4 March 2013), 2009.

Juggins, S.: Quantitative reconstructions in palaeolimnology: new paradigm or sick science?, Quaternary Sci. Rev., 64, 20-32, 2013.

Liu, J., Caroll, J. L., and Lerche, I.: A technique for disentangling temporal source and sediment variations from radioactive isotope measurements with depth, Nucl. Geophys., 5, 31-45, 1991.

Livingstone, D. M.: Break-up dates of Alpine lakes as proxy data for local and regional mean surface air temperature, Climatic Change, 37, 407-439, 1997.

Luterbacher, J., Dietrich, D., Xoplaki, E., Grosjean, M., and Wanner, H.: European Seasonal and Annual Temperature Variability, Trends, and Extremes Since 1500, Science, 303, 1499-1503, doi:10.1126/science.1093877, 2004.

Mann, M. E., Zhang, Z., Rutherford, S., Bradley, R. S., Hughes, M. K., Shindell, D., Ammann, C., Faluvegi, G., and Ni, F.: Global Signatures and Dynamical Origins of the Little Ice Age and Medieval Climate Anomaly, Science, 326, 1256-1260, 2009.

Mayewski, P. A., Rohling, E. E., Stager, J. C., Karlén, W., Maascha, K. A., Meeker, L. D., Meyerson, E. A., Gasse, F., van Kreveld, S., Holmgren, K., Lee-Thorp, J., Rosqvist, G., Rack, F., Staubwasser, M., Schneider, R. R., and Steig, E. J.: Holocene climate variability, Quaternary Res., 62, 243-255, 2004.

McCormack, F. G., Hogg, A. G., Blackwell, P. G., Buck, C. E., Higham, T. F. G., and Reimer, P. J.: SHCal04 Southern Hemisphere calibration 0-1000 cal BP, Radiocarbon, 46, 1087-1092, 2004.

Mitchell, T. D. and Jones, P. D.: An improved method of constructing a database of monthly climate observations and associated high-resolution grids, Int. J. Climatol., 25, 693-712, 2005.

Mortlock, R. A. and Fröhlich, P. N.: A simple and reliable method for the rapid determination of biogenic opal in pelagic sediments, Deep-Sea Res., 36, 1415-1426, 1989.

Neukom, R., Luterbacher, J., Villalba, R., Küttel, M., Frank, D., Jones, P. D., Grosjean, M., Wanner, H., Aravena, J.-C., Black, D. E., Christie, D. A., D’Arrigo, R., Lara, A., Morales, M., SolizGamboa, C., Srur, A., Urrutia, R., and von Gunten, L.: Multiproxy summer and winter surface air temperature field reconstructions for southern South America covering the past centuries, Clim. Dynam., 37, 35-51, doi:10.1007/s00382-010-07933, 2011.

Oksanen, J., Blanchet, F. G., Kindt, R., Legendre, P., O'Hara, R. B., Simpson, G. L., Solymos, P., Henry, M., Stevens, H., and Wagner, H.: Vegan: Community Ecology Package, available at: http://CRAN.R-project.org/package=vegan (last access: 4 March 2013), 2011.

PAGES 2k Consortium: Continental-scale temperature variability during the last two millennia, Nat. Geosci., 6, 339-346, doi:10.1038/NGEO1797, 2013.

Peters, A. and Hothorn, T.: Ipred: Improved Predictors, available at: http://CRAN.R-project.org/package=ipred (last access: 4 March 2013), 2011.

Rein, B. and Sirocko, F.: In-situ reflectance spectroscopy analysing techniques for high-resolution pigment logging in sediment cores, Int. J. Earth. Sci., 91, 950-954, doi:10.1007/s00531002-0264-0, 2002.
Rein, B., Lückge, A., Reinhardt, L., Sirocko, F., Wolf, A., and Dullo, W.-C.: El Niño variability off Peru during the last 20,000 years, Paleoceanography 20, PA4003, doi:10.1029/2004PA001099, 2005.

Saunders, K. M., Grosjean, M., and Hodgson, D. A.: A 950 year temperature reconstruction from Duckhole Lake, southern Tasmania, Australia, Holocene, 23, 771-783, doi:10.1177/0959683612470176, 2013.

Schmittner, A., Urban, N., Shakun, J. D., Mahowald, N. M., Clark, P. U., Bartlein, P. J., Mix, A. C., and Rosell-Melé, A. Climate Sensitivity Estimated from Temperature Reconstructions of the Last Glacial Maximum, Science, 334, 1385-1388, doi:10.1126/science.1203513, 2011.

SERNAGEOMIN: Mapa Géologico de Chile: version digital, Servicio Nacional de Geología y Minería, Publicación Geológica Digital, Santiago, Chile, 2003.

Simpson, G. L. and Oksanen, J.: Analogue: Analogue matching and Modern Analogue Technique transfer function models, available at: http://cran.r-project.org/package=analogue (last access: 4 March 2013), 2009.

Thompson, L. G., Mosley-Thompson, E., Davis, M. E., Zagorodnov, V. S., Howat, M., Mikhalenko, V. N., and Lin, P.-N.: Annually Resolved Ice Core Records of Tropical Climate Variability over the Past $\sim 1800$ Years, Science, 340, 945-950, doi:10.1126/science.1234210, 2013.

Trachsel, M., Grosjean, M., Schnyder, D., Kamenik, C., and Rein, B.: Scanning reflectance spectroscopy $(380-730 \mathrm{~nm})$ : a novel method for quantitative high-resolution climate reconstructions from minerogenic lake sediments, J. Paleolimnol., 44, 979-994, doi:10.1007/s10933-010-9468-7, 2010.

Trachsel, M., Kamenik, C., Grosjean, M., McCarroll, D., Moberg, A., Brázdil, R., Büntgen, U., Dobrovolný, P., Esper, J., Frank, D.C., Friedrich, M., Glaser, R., Larocque-Tobler, I., Nicolussi, K., and Riemann, D.: Multi-archive summer temperature reconstruction for the European Alps, AD 1053-1996, Quaternary Sci. Rev., 46, 66-79, 2012.

Tylmann, W., Enters, D., Kinder, M., Moska, P., Ohlendorf, C., Poręba, G., and Zolitschka, B.: Multiple dating of varved sediments from Lake Łazduny, northern Poland: Toward an improved chronology for the last 150 years, Quat. Geochronol., 15, 98$107,2013$.

van Geel, B., Buurman, J., and Waterbolk, H. T.: Archaeological and palaeoecological indications of an abrupt climate change in The Netherlands, and evidence for climatic teleconnections around 2650 BP, J. Quat. Sci., 11, 451-460, 1996.

Villalba, R., Lara, A., Boninsegna, J. A., Masiokas, M., Delgado, S., Aravena, J., Roig, F., Schmelter, A., Wolodarsky, A., and Ripalto, A.: Large-scale temperature changes across the southern Andes: 20th century variations in the context of the past 400 years, Climatic Change, 59, 177-232, 2003.

Villalba, R., Grosjean, M., and Kiefer, T.: Long-term multiproxy climate reconstructions and dynamics in South America (LOTRED-SA): State of the art and perspectives, Palaeogeogr. Palaeocl., 281, 175-179, 2009.

von Gunten, L.: High-resolution, quantitative climate reconstruction over the past 1000 years and pollution history derived from lake sediments in Central Chile. Dissertation, University of Bern, $1-119,2009$. 
von Gunten, L., Grosjean, M., Beer, J., Grob, P., Morales, A., and Urrutia, R.: Age modeling of young non-varved lake sediments: methods and limits. Examples from two lakes in Central Chile, J. Paleolimnol., 42, 401-412, doi:10.1007/s10933-008-9284-5, 2009a.

von Gunten, L., Grosjean, M., Rein, B., Urrutia, R., and Appleby, P.: A quantitative high-resolution summer temperature reconstruction based on sedimentary pigments from Laguna Aculeo, central Chile, back to AD 850, Holocene, 19, 873-881, doi:10.1177/0959683609336573, 2009b.

Von Gunten, L., Grosjean, M., Kamenik, C., Fujak, M., and Urrutia, R.: Calibrating biogeochemical and physical climate proxies from non-varved lake sediments with meteorological data: methods and case studies, J. Paleolimnol., 47, 583-600, doi:10.1007/s10933-012-9582-9, 2012.
Wanner, H., Beer, J., Bütikofer, J., Crowley, T.J., Cubasch, U., Flückiger, J., Goosse, H., Grosjean, M., Joos, F., Kaplan, J. O., Küttel, M., Müller, S. A., Prentice, I. C., Solomina, O., Stocker, T. F., Tarasov, P., Wagner, M., and Widmann, M.: Mid- to Late Holocene climate change: an overview, Quaternary Sci. Rev., 27, 1791-1828, 2008.

Warnes, G. R.: Gdata: Various R programming tools for data manipulation, http://CRAN.R-project.org/package=gdata (last access: 4 March 2013), 2010. 